\title{
A threat to "the very heart" of academic freedom
}

\section{London}

THAT academics of all political persuasion seem to be united in their opposition to the Education Reform Bill was made clear at a seminar last week, organized by Nature and attended by nearly 100 politicians and leading academics. Two principal conclusions emerged: first, that there is an overwhelming degree of consensus on the issues, and that many of the government's keenest supporters are incensed by the proposals; and second, that the universities need to learn quickly how to win new friends and influence people, something that they have woefully neglected to do in the past.

The bill is not much concerned with higher education, but the few short clauses relating to universities have farreaching implications, opening the way for direct political intervention in the management of individual departments within institutions. Professor Sir Mark Richmond, vice-chancellor of the University of Manchester and chairman of the Committee of Vice-Chancellors and Principals (CVCP), told the seminar that the bill, if enacted, would "strike at the very heart of academic freedom".

The bill proposes to create new funding bodies for the university and polytechnic sectors. The creation of a Universities Funding Council (UFC) to replace the University Grants Committee (UGC) is not in itself contentious. What have horrified the academic community are clauses in the bill that would establish a "chain of command', with the secretary of state able to give specific instructions to the funding councils which would impose conditions on institutions. Failure of a university to comply with UFC's directions would require the repayment, with interest, of any grants received through the UFC.

Richmond argues that if the aim of the bill, as far as it affects universities, is to create a system under which institutions can be forced to adapt to economic circumstances, then it is misguided. "Change is already happening. The legislation designed to bring about this change actually threatens to slow its progress. It will hinder. It will hamper. It could prove to be a serious constraint to those who want to manage well and responsibly."

Further, a mechanism that allows ministerial intervention (through conditions imposed on the funding council) in an individual department of a university threatens three fundamental freedoms: "the freedom to research in subjects of as yet unrecognized importance, the freedom to question received wisdom; and the freedom to be protected from direct and narrow political interference by the government of the day."

That the universities are capable them- selves of instigating change is self-evident, says Richmond. Since the cuts of $1980-$ 81 , teaching staff has fallen by 12 per cent Student numbers were at an all-time high of 301,000 by $1986-87$. Numbers of parttime students and short courses, many run for industry, have also proliferated. Total research income since $1981-82$ is up by 85.7 per cent, with the rate of increase of earnings from industry and commerce outstripping that from the research councils. Overall, the proportion of income from block grants is now 57 per cent, compared with 77 per cent a decade ago. Consultancy and applied research activities hardly existed before 1980, says Richmond. Now around 100 university companies provide such services, with more than 500 spin-off companies.

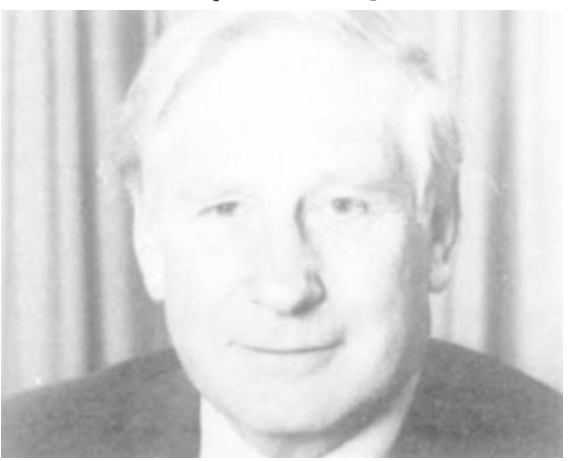

Sir Mark Richmond will discuss his view that "change is already happening" in a forthcoming Commentary.

The proposals contained in the bill would hinder an institution's ability to innovate, he says. Clause 94(3) reads: "The Secretary of State may make grants to each of the funding councils of such amounts and subject to such conditions as he may determine"; and clause 94(4): "In exercising their function ... each of the funding councils shall comply with any directions given to them by the Secretary of State". Clause 92(6) reads: "The [funding] councils shall have power to make payments subject to such terms and conditions as they think fit". A later clause enables the council to reclaim any funds, with interest, if conditions are not met.

The possibility of secondary legislation is also causing concern. Last summer, the Department of Education and Science (DES) produced a consultation document which proposed that allocation of money from the funding councils would be in the form of contracts - leaving open the possibility that an individual university's funding would comprise a large number of specific 'mini-contracts', precluding the possibility of switching funds from one to another. Although the bill does not contain the word 'contract', it does refer to "payments subject to terms and conditions".

Richmond denies the government's claim that the proposed system, because it will be defined in law, will be clearer and more limited than the all-embracing power presently resting with the secretary of state. (The UGC is effectively a subcommittee of the DES.) At present, the UGC advises the government on the block grant to be paid to each university, which is handed over in one lump sum, to be spent as the university thinks best - subject to scrutiny by its own auditors and the National Audit Office. The UGC can offer 'advice', which can be ignored, on the understanding that such action could lead to grant cuts in future, "but very different from a detailed and binding instruction, backed with the ability to demand repayment of grant with interest, which this bill would allow".

Richmond decries the notion that costeffectiveness should be the criterion by which to manage a university. Universities, he says, are in part businesses whose product is ideas, and that as such it would be inappropriate for politicians or civil servants to set themselves up as commissioning agents. "Who, in Whitehall, or indeed anywhere else, would for example have written a contract in advance for one A. Einstein to produce the research published in the Annalen der Physik in 1905 under the title $A$ new determination of molecular dimensions?".

The degree of concern expressed at the seminar was typified by Professor Henry Chadwick, master of Peterhouse, Cambridge. About clause 94(1), which allows the secretary of state to confer additional functions on the funding council "as he thinks fit", he said: "I am alarmed that the bill confers powers on the secretary of state to tell scientists and scholars precisely what to do. He only has to get it wrong once for the brain drain to reach an unprecedented scale." The clause is, he said, "insufferable in a free democratic society".

Sir Patrick Neill, vice-chancellor of the University of Oxford and vice-chairman of the CVCP, says amendments are being drafted to curb the secretary of state's powers of direct intervention. Lord Flowers, vice-chancellor of the University of London, suspected that the offending clauses were the work of civil servants "who have an eye on the future".

It was for Labour peer Lady White and the Liberal leader in the House of Lords, Lady Seear, to offer the practical advice to lobby local members of parliament, particularly Conservative back-benchers, and in the Lords to focus on cross-bench peers. There was little dissent from the view of Professor Norman Saunders, of the University of Southampton, that the price is now being paid for the failure of the universities to raise their public profile to demonstrate their integral role in the nation's culture.
Simon Hadlington 